\title{
PROBLEMATIKA PERNIKAHAN GENERASI MILENIAL TERHADAP KASTA DI BALI
}

\author{
G.A. Amanda Kristina Damayanti \\ Sekolah Tinggi Ilmu Ekonomi Panca Bhakti Palu \\ amandakristina25@gmail.com
}

\begin{abstract}
Riwayat Jurnal
Artikel diterima: 1 Juli 2020

Artikel direvisi: 21 Nopember 2020

Artikel disetujui: 29 Desember 2020
\end{abstract}

\begin{tabular}{|l|l|} 
Kata Kunci: & Abstrak \\
Generasi Milenial & Catur varna adalah empat penggolongan masyarakat berdasarkan \\
bakat (guna)/keahlian dan keterampilan (karma)/profesi \\
Catur Varna \\
Peseorang. Namun para penjajah memberikan pemahaman yang \\
keliru tentang penggolongan masyarakat ini, sehingga \\
pemahaman kasta dikaburkan dengan catur varna yang dalam \\
penerapannya sangat jauh berbeda dengan makna yang ada dalam \\
kitab suci. Kurangnnya pemahaman kitab suci menyebabkan \\
kesalahpahaman ini terus berlanjut hingga saat ini sehingga terjadi \\
banyak pertentangan di kalangan masyarakat hindu bali. Era \\
milenial yang serba canggih ini menjadikan tidak batasan yang \\
mempersulit keadaan kehidupan manusia karena semua kalangan \\
telah saling terkoneksi satu dengan yang lainnya. Hal tersebut \\
memberi dampak pada memudahnya generasi milenial dalam \\
menemukan teman hidupnya baik online maupun offline, \\
walaupun terkadang adat dan istiadat yang berlaku menjadi \\
hambatan dalam kebebasan kaum milenial dalam menentukan \\
pasangan hidupnya. Masih banyak yang menjunjung tinggi \\
budaya warisan penjajah yang menjadikan kasta dan varna \\
menjadi permasalahan yang terus-terusan terjadi hingga saat ini.
\end{tabular}




\begin{tabular}{|l|l|}
\hline & $\begin{array}{l}\text { partners both online and offline, even though sometimes the } \\
\text { customs and traditions that apply become obstacles to millennial } \\
\text { freedom in determining their life partners. There are still many } \\
\text { who uphold the cultural heritage of the colonialists, which makes } \\
\text { caste and varnas a problem that continues to this day. }\end{array}$ \\
\hline
\end{tabular}

\section{Pendahuluan}

Pada masa ini kata "kasta" dalam masyarakat Hindu di Bali bukan merupakan hal yang asing lagi. Hal tersebut telah ada secara turun temurun sejak kedatangan India dalam menyebarkan ajaran Hindu di Bali. Seiring perkembangan jaman hal ini telah banyak menjadi kontra dikehidupan masyarakat Hindu di Bali, hal itu terjadi akibat kurangnya pemahaman dan edukasi tentang ajaran agama Hindu. Dalam kitab suci agama Hindu tidak dikenal istilah 'kasta' melainkan adanya catur varna. Wiana (2005) Warna merupakan penggolongan masyarakat berdasarkan fungsi dan profesi. Catur varna merupakan sistem pengelompokan masyarakat berdasarkan profesi atau keahlian yang dimiliki sedangkan kasta merupakan pengelompokan masyarakat berdasarkan keturunan atau kelahiran. Kedua hal ini adalah hal yang berbeda juga memiliki artian yang sangat jauh berbeda. Namun kurangnya pemahaman ini menjadikan sebagian masyarakat lebih familiar dengan kata kasta dibanding catur varna.

Kesalahpahaman terntang Varna yang terjadi sejak masa penjajahan berdampak pada lebih dikenalnya Kasta dibandingkan dengan Varna. Penjajah telah mengaburkan sistem catur varna dengan tujuan untuk memecah belah kehidupan masyarakat Hindu di Bali, sehingga terdapat jarak kehidupan antara raja dan rakyatnya kedalam kelompok-kelompok kasta. Hal tersebut terjadi hingga saat ini masyarakat mulai melupakan ajaran catur varna dan lebih mengenal sistem kasta. Keadaan tersebut sangat berdampak pada kehidupan masyarakat Hindu baik di Bali maupun luar Bali, karena sangat berkaitan erat dengan tatanan kehidupan masyarakat.Dewasa ini perkembangan teknologi dan informasi begitu cepat sehingga hampir tak ada batasan dalam berkenalan dan bertemu orang baru, dari orang dewasa hingga anakanak dengan memanfaatkan fasilitas koneksi internet. Teknologi yang demikian canggih memudahkan dalam berkomunikasi baik jarak dekat maupun jarak jauh dan bahkan dengan orang yang ada diseluruh dunia. Perkembangan tersebut dapat memudahkan seseorang dalam bertemu dan berkenalan dengan orang baru lebih banyak. Pertemanan sangat mudah dilakukan di dunia maya, bahkan ada yang hingga dapat menemukan pasangan hidup yang akhirnya menikah. 


\section{G.A. Amanda Kristina Damayanti}

Generasi Milenial atau yang berada pada usia 25-40 Tahun dapat memanfaatkan teknologi sebagai alat dalam mencari pasangan hidup. Seseorang dapat secara bebas dalam menentukan pasangan hidupnya sesuai dengan kreteria yang diharapkan. Akan tetapi hal tersebut terkadang menjadi sebuah permasalahan ketika telah melanjutkan pada tahap pernikahan, karena ada beberapa orang tua yang masih berpegang erat pada kekeliruan dalam memahami Varna. Pada fase inilah istilah kasta mulai mencuat dalam kehidupan seseorang dikarenakan penggolongan tersebut dijadikan sebuah dasar dalam menentukan pasangan. Kurangnya ilmu pengetahuan dan pemahaman tentang kesalahpahaman atas kasta secara turun temurun menjadikan hal ini sebagai pertimbangan khusus bagi sebagian orang dalam memilih pasangan hidupnya. Oleh karena itu pemahaman tentang catur Varna yang komprehensif dapat meminimalisir terjadinya pro kontra dalam pernikahan para generasi milenial terutama pasangan yang berbeda varna.

\section{Pembahasan}

Di era teknologi yang kian pesat ini menyebabkan banyak perubahan terhadap berbagai bidang secara cepat dan tak terhentikan, arus informasi dan teknologi yang diterima membawa dampak positif terhadap berbagai hal. Salah satu bidang yang juga terdampak dalam hal ini adalah tentang kebudayaan, adat dan istiadat dan juga perkembangan agama itu sendiri. Hal ini pula tak luput dari efek negatif yang menimbulkan perubahan kehidupan diberbagai daerah termasuk di Bali hal ini ditandai dengan memudarnya kebudayaan di Bali.

Orang di Bali dikenal dengan orang yang taat dan tidak melupakan asal muasal mereka berasal. Hal ini kemudian melahirkan berbagai macam golongan berdasarkan profesi yang dikenal dengan istilah catur varna. Pembagian masyarakat menurut swadharma (profesi) masing-masing orang, profesi itu adalah brahmana (sebagai pemikir), ksatrya (pelaksana pemerintahan), wesia (pengusaha), dan sudra (pekerja) (Putra, 2017). Namun istilah Varna tidak begitu banyak diketahui oleh masyarakat bahkan istilah ini mulai menghilang seiring perkembangan teknologi. Masyarakat lebih mengenal istilah kasta dalam kehidupannya seharihari, dimana istilah ini tidak ada dalam ajaran agama hindu. Istilah kasta dibawa oleh penjajah pada saat menjajah wilayah Bali. Kesalahpahaman inilah yang menjadi masalah terbesar seseorang yang akan melangkah menuju pernikahan dikalangan milenial saat ini, teknologi membawa informasi yang salah menjadi semakin tersebar ke berbagai daerah.

\section{Kesalahpahaman antara Kasta dan Catur Varna}




\section{G.A. Amanda Kristina Damayanti}

Kasta di Bali diawali dengan banyaknya kerajaaan kerajaan kecil yang ada dan dikacaukan dengan kedatangan penjajah Belanda yang memecah belah politik di Bali. Sesungguhnya kasta merupakan salah satu taktik dari penjajah pada masa kolonial Belanda yang mencoba untuk mempengaruhi dan memecah belah persatuan dan kesatuan masyarakat Bali, sehingga mudah untuk ditaklukan (Sudarsini, 2018). Kasta dibuat menyerupai catur varna yang ada dalam ajaran agama Hindu, namun dalam penerapannya orang yang berkuasa mengadu domba kelompok masyarakat ini agar tidak bersatu. Banyak masyarakat yang dibuat bingung antara kasta dan juga catur varna ini. kesalahpahaman ini semakin berkembang dikalangan masyarakat bali hingga saat ini.

Catur Varna dalam agama Hindu diturunkan melalui wahyu dari Tuhan yang dituangkan dalam kitab suci Veda. Yang tujuannya bukan untuk membeda-bedakan kelompok atau satu golongan dengan golongan lainnya. Catur varna ini ada disebabkan karna profesi dan kemampuan atau keahlian yang ada. Beberapa kitab suci agama Hindu lainnya yang menyebutkan tentang warna, terdapat dalam Reg Weda (X.90.12), Yajur Weda (XVIII. 38), Yajurveda (XVIII.48), Yajur Weda (XXXI.II), Bhagavadgita (XVIII.41), Yajurveda (XXV.2), Yajurveda (XXX.5), Yajurveda (XXX.11), Manawa Dharmasastra (X.4), Sarasamuscaya sloka 55, Sarasamuccaya sloka 57, Sarasamuccaya sloka 58, Sarasamuccaya sloka 59 dan Sarasamuccaya sloka 60. Kitab suci Hindu lainnya seperti itihasa juga mencantumkan catur warna, salah satunya dalam Mahabharata (XII.CCCXII,108) yang menyatakan bahwa keDvijati-an atau lahir untuk yang kedua kalinya (reinkarnasi) seseorang tidak ditentukan oleh ke-wangsa-annya (nayonih), namun hal yang menentukannya adalah perbuatan yang luhur dan pekerjaanya yang memberi bimbingan rohani kepada masyarakat juga merupakan bhaktinya semasa hidupnya.

Catur varna dalam untaian salah satu kitab suci Yajur Veda, XXX.5 menyebutkan :

"Brahmane Brahmanam,

Kshtariya Rajanyam,

Marudbhyo Vaishyam,

Tapase Sudram”

Terjemahannya :

Tuhan telah menciptakan Brahmana untuk pengetahuan,

Ksatria untuk perlindungan,

Vaishya untuk perdagangan dan 


\section{G.A. Amanda Kristina Damayanti}

\section{Sudra untuk pekerjaan jasmani}

Sangat jelas ayat ini menjelaskan secara tegas konsep catur warna dalam agama hindu adalah yang berdasarkan atas profesi dan kemampuan atau keahlian, namun seiring penyebaran informasi yang tidak terfilter dengan baik pertanyaan lain muncul yang justru menyamakan ajaran catur varna dengan kasta. Perkembangan informasi justru membuat pandangan baru dan menganggap bahwa pembagian dari segi profesi dan keahlian ini diangap sangat tidak jauh berbeda dengan sistem kasta yang berasal dari budaya luar ini, yaitu samasama mengklasifikasikan atau megelompokan seseorang dalam kelompok yang berbeda dengan yang lainnya.

Catur warna sesungguhnya bukan bertujuan untuk membentuk masyarakat berkelompok-kelompok atau terkotak-kotakan secara vertikal, namun menjelaskan bahwa setiap manusia memiliki keahlian atau kemampuan yang berbeda, memiliki karakter, sifat dan potensi yang berbeda satu dengan yang lainnya, namun masih berada dalam satu koridor yang sama secara horizontal yaitu manusia sebagai mahluk ciptaan Tuhan.

Rumusan catur warna terdapat dalam Bhagawadgita IV,13 dan XIII, 41

Caturvarnyah maya srstam guna

karma vibhagasah tasya

kartaram api mam viddhy

akartaram avyayam.

Terjemahannya :

Caturvarna Kuciptakan menurut pembagian guna dan karma, meskipun Aku sebagai penciptanya, ketahuilah Aku mengatasi gerak dan perubahan"

Semua hal yang ada dimuka bumi ini sebenarnya sudah ada tertera dalam kitab suci namun tak semua orang mau mendalami dan mempelajari kitab suci sehingga banyak yang salah kaprah dalam mengartikan suatu fenomena. Hingga kini sebagian masyarakat di bali masih banyak yang salah paham dengan ajaran catur varna dangan mengaitkan kasta dalam pengertiannya.

\section{a. Brahmana}




\section{Problematika Pernikahan Generasi Milenial Terhadap Kasta Di Bali}

\section{G.A. Amanda Kristina Damayanti}

Brahmana merupakan golongan orang-orang cendekiawan yang mampu menguasai ajaran, ilmu pengetahuan, adat, adab hingga ajaran keagamaan seperti pendeta dan rohaniawan dalam suatu masyarakat, sehingga golongan tersebut mereka merupakan golongan yang paling dihormati. Dalam ajaran Catur Varna, Seseorang dikatakan menyandang gelar Brahmana karena keahliannya dalam bidang pengetahuan keagamaan.

Pada bait pertama mantram Yajurveda Sloka ke 30, 5 berbunyi:

\section{"Brahmane Brahmanam”,}

Terjemahannya :

"Ya Tuhan Yang Maha Esa telah menciptakan Brahmana untuk pengetahuan",

Orang- orang yang masuk dalam golongan brahmana ini adalah orang yang berprofesi sebagai guru, guru spiritual, pemangku (pinandita) dan Pandita (begawan, mpu, pedanda). Namun pada saat ini kesalahpahaman terjadi dimana banyak masyarakat yang salah dalam menentukan kelompok mereka sendiri seperti halnya menentukan kelompok brahmana yang dinilai saat ini hanya untuk orang yang berdasarkan garis keturunan leluhur mereka pada masa lampau yang memiliki gelar atau nama depan "Ida Bagus" untuk laki-laki dan "Ida Ayu" untuk perempuan. Hal seperti ini sebenarnya tidak terdapat pada kitab suci agama Hindu hanya saja ini kesalahpahaman ini berlanjut hingga saat ini dimana setiap manusia yang lahir berasal dari leluhur yang pada masa lampau sebagai pemuka agama atau yang disebut rohaniawan masuk dalam golongan ini walaupun mereka tidak memiliki keahlian atau profesi yang sesuai dengan golongan brahmana sesuai dengan ajaran yang ada dalam kitab suci agama hindu. Mereka masih menerapkan sistem kasta karena merupakan warisan dari leluhur pada masa lampau.

\section{b. Ksatriya}

Ksatriya dalam catur varna merupakan golongan yang dianggap sebagai bangsawan pada masa lampau yang juga merupakan golongan para kesatria ataupun para prajurit raja. Pada masa kini ksatriya ini merupakan golongan orang orang yang orang menekuni bidang pemerintahan atau administrasi negara dan yang ahli dalam bidang militer dan mahir menggunakan senjata. Mereka memiliki kewajiban sebagai pelindungi golongan Brahmana, Waisya, dan Sudra. Kesatria atau ksatrya, adalah tingkatan kedua dari catur varna dalam agama Hindu. Golongan ksatria ini merupakan tokoh masyarakat yang berprofesi atau bertugas sebagai penegak keadilan, penegak keamanan, pemimpin dalam masyarakat, yang bertugas 


\section{G.A. Amanda Kristina Damayanti}

sebagai pembela kaum atau golongan yang tertindas atau lemah karena ketidakadilan yang terjadi dan ketidakbenaran akan suatu hal.

Golongan ksatriya terdapat dalam bait kedua mantram Yajurveda sloka 31, 11 menyatakan:

\section{"Bahu Rajanyah Krtah”,}

Terjemahannya :

"Ksatriya lengan-lengan-Nya",

Bait sloka di atas menjelaskan bahwa jika dianatomikan sebagai tubuh manusia dalam tatanan masyarakat, ksatriya berperan sebagai pelindung yang menggunakan seluruh kekuatan tangannya untuk melindungi anggota tubuh yang lain yang jika diimplementasikan penerapannya dalam kehidupan masyarakat mereka bertugas melindungi suatu negara beserta isinya. Hingga saat ini ksatriya dalam catur varna masih dilekat eratkan dengan sistem kasta yang hingga saat ini lebih familiar dibanding catur varna, orang-orang menganggap warisan dengan gelar keturunan "Anak Agung" (disingkat Gung), "Cokorda" (disingkat Cok), "Desak" atau "Gusti" juga menggunakan gelar "Dewa" untuk laki-laki, atau "Dewa Ayu" untuk perempuan, masuk dalam golongan kesatriya. Di zaman dahulu ksatria merujuk pada kelas masyarakat kasta bangsawan atau tentara, hingga raja. Namun hingga kini keturunannya masih menggolongkan diri mereka kedalam golongan ksatriya karena mewariskan nama-nama ini walaupun mereka tidak memiliki profesi dan keahlian sebagaimana ksatriya ini diartikan dalam kitab suci hindu.

\section{c. Waisya}

Dalam kitab Yajurveda bait ketiga Sloka ke 30, 5 berbunyi:

\section{"Marudbhyo Vaisyam"}

Terjemahannya:

\section{"Para Vaisya untuk perdagangan”,}

Pada bait tersebut mengartikan bahwa golongan waisya memiliki keahlian dan tugas dibidang perdagangan atau perekonomian yang bersifat materil. Bakat dasar yang dimiliki golongan waisya ini adalah disiplin, tekun, hemat, penuh perhitungan, cermat, terampil, serta memiliki kemampuan dalam mengelola segala hal yang berhubungan dengan aset 


\section{G.A. Amanda Kristina Damayanti}

(kepemilikan). Setelah terjadi penjajahan di Bali penjajah memecah belah kelompok masyarakat dan mengalih fungsikan sistem catur varna menjadi kasta. Dimana pada jaman dahulu kasta waisya ini erat kaitannya dengan orang yang berprofesi sebagai pedagang, namun saat ini masih banyak masyarakat yang menganggap bahwa kasta ini merupakan budaya yang berasal dari Bali yang harus dijaga hingga saat ini dengan menjadikan keturunan orang yang dahulu menyandang gelar waisya juga masuk kedalam golongan ini, walaupun keturunan mereka saat ini tidak memiliki keahlian dan profesi sebagai pedagang secara otomatis telah menyandang golongan ini. kesalahpahaman ini terus berlanjut hingga saat ini, mereka mewariskan keturunan mereka dengan menggunakan nama yang diawali dengan "Ngakan", "Kompyang”, "Sang”, atau "Si". Menurut orang-orang ini apabila seseorang lahir dari orang yang memiliki nama awalan tersebut secara langsung masuk kedalam golongan waisya. Hal ini tidak sesuai dengan ajaran agama hindu yang terdapat dalam kitab suci, sebagaimana yang diketahui sebagai pedoman dalam menjalani kehidupan.

\section{d. Sudra}

Sudra (Sanskerta: śūdra) adalah merupakan sebuah golongan orang orang yang memiliki profesi (golongan karya) juga keahlian yang mengandalkan kekuatan jasmani atau tenaga yang dimiliki. Dalam ajaran catur varna ini sudra warna merupakan golongan yang paling rendah atau golongan paling akhir. Varna lainnya adalah brahmana, ksatria, dan waisya.

Ketaatan, kepolosan, keluguan, serta bakat ketekunannya yang menjadi dasar golongan ini ada. Tugas utamanya golongan ini berkaitan langsung dengan tugas-tugas yang bertujuan memakmurkan seluruh kalangan masyarakat dalam suatu negara dan seluruh umat manusia atas petunjuk-petunjuk yang ada dalam kitab suci. Hal ini sesuai dengan mantram yang tertera dalam kitab Yajur Veda XXX.5 baik keempat yang berbunyi :

\section{tapase sudram}

Terjemahannya :

\section{para sudra untuk pekerja jasmaniah}

Sangat jelas yang dimaksudkan adalah golongan sudra menggunakan kekuatan badannya untuk melakukan pekerjaannya dengan sepenuh tenaga. Petunjuk lainnya juga terdapat dalam mantram-mantram Yajurveda sloka 31, 11 berbunyi : 


\section{Problematika Pernikahan Generasi Milenial Terhadap Kasta Di Bali}

\section{G.A. Amanda Kristina Damayanti}

\section{Padbhyam Sudro Ajayata}

Terjemahannya :

\section{Sudra kaki-kaki-Nya}

Maksud dari mantram ini adalah sudra sebagai bagian yang menopang anggota tubuh yang lainnya, memiliki tugas dan beban yang lebih berat secara fisik sehingga diibaratkan dengan kaki yang memiliki tugas paling berat saat menggerakkan anggota tubuh yang lain. Bergerak maju dan melangkah secara optimal, tanpa kaki anggota tubuh yang lainnya tidak dapat maju dan melangkah secara efisien. Pada masa lalu, penamaan dan pemberian gelar berdasarkan urutan kelahiran anak yang cenderung digunakan orang-orang Bali dari golongan kasta-kasta atas (Brahmana, Ksatriya, Waisya) sedangkan orang-orang Bali yang berkasta sudra tidak mau menggunakan pola penamaan tersebut. Pada masa itu mereka yang bergolongan sudra memberikan nama anaknya dengan awalan I untuk anak laki-laki atau Ni untuk anak perempuan. Seiring dengan perkembangan jaman golongan ini menamakan keturunan mereka dengan menambahkan urutan kelahiran dari seorang anak tersebut dengan tidak meninggalkan awalan i dan ni tersebut. Nama-nama berdasarkan urutan kelahiran tersebut seperti : "Wayan", "Putu", "Gede", "Made", "Kadek", "Nengah", "Nyoman", “Komang”, dan "Ketut”.

Hingga saat ini penggunaan nama-nama ini dianggap sebagai penentu golongan sudra ini namun hal ini tidak sesuai dengan ajaran catur varna dimana menyebutkan bahwa golongan seseorang ditentukan berdasarkan keahlian dan profesi seseorang bukan berdasarkan warisan gelar keterunan dari leluhur mereka. Dalam Bhagavadgita IV sloka ke-13 ditulis:

\section{"Chatur Varnyam Maya Srishtam,}

Guna Karma Vibhagasah,

Tasya Kartaram Api Mam,

Viddhy Akartaram Avyayam"

Terjemahannya :

"catur warna adalah ciptaan-Ku, menurut pembagian kualitas dan kerja, tetapi ketahuilah walaupun penciptanya, Aku tidak berbuat dan mengubah diri-Ku." 


\section{G.A. Amanda Kristina Damayanti}

Sangat jelas bahwa dalam sloka ini adanya catur varna adalah sebagai bentuk pengelompokan sesuai dengan profesi atau bidang kerja masing-masing yang dilaksanakan dan dikerjakan oleh seseorang berdasarkan bakat, minat dan keahlian yang dimilikinya; bukan sebagai alat pembeda derajat antar sesama manusia yang diantaranya karena masing-masing dari mereka menjalankan karma dengan saling melengkapi.

Dalam ajaran catur warna, status seseorang akan didapatkan sesuai dengan keahlian dan pekerjaannya. Sehingga dalam konsep ini diuraikan bahwa bukanlah keturunan yang menentukan status seseorang meskipun seseorang tersebut lahir, tumbuh dan besar dalam keluarga Sudra atau Waisya belum tentu seseorang tersebut menyandang gelar tersebut, akan tetapi apabila seseorang tersebut telah menekuni bidang kerohanian dan menjadi seorang pendeta, maka ia secara langsung berhak menyandang status Brahmana (rohaniawan). Sangat berbeda dengan sistem kasta, status seseorang didapatkan semenjak ia terlahir, jika ia lahir dalam keluarga Brahmana maka ia secara langsung menyandang status Brahmana. Jadi berdasarkan ajaran Hindu, Catur Warna merupakan status yang didapatkan ketika seseorang menekuni suatu keahlian atau profesi dan tidak didapat sejak ia lahir.

\section{Problematika pernikahan kasta di Bali.}

Dalam agama Hindu di Bali istilah perkawinan biasa disebut Pawiwahan. Pengertian Pawiwahan itu sendiri dari sudut pandang etimologi atau asal katanya, kata pawiwahan berasal dari kata dasar "wiwaha". Dalam Kamus Bahasa Indonesia disebutkan bahwa kata wiwaha berasal dari bahasa sansekerta yang berarti pesta pernikahan; perkawinan (Departemen Pendidikan dan Kebudayaan, 1997:1130). Menurut Thalib (1980), perkawinan ialah suatu perjanjian yang suci kuat dan kokoh untuk hidup bersama secara sah antara seorang laki-laki dengan seorang perempuan untuk membentuk keluarga yang kekal, santun-menyantuni, kasihmengasihi, tenteram dan bahagia.

Menurut Undang-undang Nomor 1 Tahun 1974 (pasal 1), perkawinan itu ialah ikatan lahir batin antara seorang pria dengan seorang wanita sebagai suami istri dengan tujuan membentuk keluarga (rumah tangga) yang bahagia dan kekal berdasarkan Ketuhanan Yang Maha Esa. Pertimbangannya ialah sebagai negara yang berdasarkan pancasila dimana sila yang pertama ialah Ketuhanan Yang Maha Esa, maka perkawinan mempunyai hubungan yang erat sekali dengan agama/kerohanian, sehingga perkawinan bukan saja mempunyai unsur lahir/ jasmani, tetapi unsur batin/ rohani juga mempunyai peranan yang penting. 


\section{G.A. Amanda Kristina Damayanti}

Perkawinan merupakan sebuah peristiwa sakral, suci dan merupakan kewajiban bagi umat Hindu. Sebagaimana Tuhan telah bersabda dalam Manava dharmasastra IX. 96 sebagai berikut:

"Prnja nartha striyah srstah samtarnartham ca manavah.

Tasmat sadahrano dharmah crutam patnya sahaditah"

Terjemahannya :

"Untuk menjadi Ibu, wanita diciptakan dan untuk menjadi ayah, laki-laki itu diciptakan. Upacara keagamaan karena itu ditetapkan di dalam Veda untuk dilakukan oleh suami dengan istrinya"

Dapat dijelaskan berdasarkan kitab tersebut bahwa untuk menjadi seorang ibu, wanita telah diciptakan Tuhan dan ditakdirkan untuk menjadi ibu, merupakan kodrat wanita untuk menjalani tugas sebagai ibu. sedangkan untuk menjadi ayah seorang laki-laki itu diciptakan artinya laki-laki ditakdirkan untuk menjadi bapak, dan merupakan kodratnya untuk menjadi seorang bapak. Dalam pernikahan agama hindu dijelaskan dalam kitab memiliki tujuan yang mulia yaitu untuk mendapatkan keturunan yang akan meneruskan peradaban di bumi dan menurunkan seorang putra/putri yang suputra guna membantu menebus dosa para orang tua. sehingga akan terciptanya sebuah keluarga yang berbahagia di dunia (jagadhita) dan menuju kebahagiaan kekal (moksa). Dalam ajaran agama Hindu sebuah pernikahan diharapkan tidak terjadi dan tidak menginginkan adanya perceraian. Bahkan sebaliknya, sangat dianjurkan agar sebuah perkawinan yang damai, bahagia dan kekal hendaknya hal ini dijadikan sebagai sebuah tujuan mulia dan yang tertinggi bagi pasangan suami istri. Seperti yang disebutkan dalam kitab Manawa Dharmasastra IX.102 berbunyi :

"Tatha nityam yateyam stripumsau

tu kritakriyau,

Jatha nabhicaretam tau

wiyuktawitaretaram"

Terjemahannya :

"Hendaknya laki-laki dan perempuan yang terikat dalam 


\section{G.A. Amanda Kristina Damayanti}

ikatan perkawinan, mengusahakan dengan tidak jemu-jemunya supaya mereka tidak bercerai dan jangan hendaknya melanggar kesetiaan antara satu dengan yang lain”

Pada ayat ini menjelaskan bahwa pernikahan itu hendaknya dipertahankan, dijaga keutuhannya, selalu setia, dan dijaga agar tidak terjadi perpisahan atau yang biasa disebut perceraian. Pernikahan yang diharapkan dapat membawa kebahagiaan lahir dan batin yang kekal. Hal inipun tertera dalam kitab Manawa Dharma sastra III. 60 , sebagai berikut:

\section{"Samtusto bharyaya bharta bharta tathaiva ca, Yasminnewa kule nityam kalyanam tatra wai dhruwam"}

Terjemahannya :

"Pada keluarga dimana suami berbahagia dengan istrinya dan demikian pula sang istri terhadap suaminya, kebahagiaan pasti kekal"

Pernikahan yang memiliki tujuan sebagai jalan menuju dharma membawa kebaikan dan hendaknya diberlangsungkan sekali semasa hidup hingga akhir hayat sesuai dengan sabda Tuhan dalam kitab Manava Dharmasastra IX. 101-102 sebagai berikut:
"Anyonyasyawayabhicaro bhawedamaranantikah, Esa dharmah Samasena jneyah stripumsayoh parah"

Terjemahannya :
"Hendaknya supaya hubungan yang setia berlangsung sampai mati, singkatnya ini harus dianggap sebagai hukum tertinggi sebagai suami istri”.

Dalam kitab suci agama hindu sudah sangat jelas tertera segala aturan kehidupan yang apabila dijalani dengan tulus ikhlas akan mendapatkan kebahagiaan hidup yang sebenarbenarnya dengan terciptanya keluarga bahagia dan kekal maka kebahagiaan yang kekal akan tercapai pula dan dapat menghantarkan kejalan menuju dharma. Namun saat ini yang terjadi kurangnya literasi dan pemahaman akan kerohanian seseorang membuat banyak ideologi baru 


\section{G.A. Amanda Kristina Damayanti}

terhadap aturan kehidupan, salah satunya aturan yang mengatur tentang kehidupan berumah tangga, dalam kitab suci dijelaskan secara rinci segala yang hendaknya patut dijalankan dan dijadikan sebagai pedoman seluruh umat manusia, akan tetapi ideologi baru masuk dan merusak sistem yang telah ada ini, sehingga membuat kekacauan yang memecah belah banyak pihak termasuk pernikahan kasta. Jika menyebutkan tentang pernikahan kasta hal ini tidak luput dari orang bali dan agama hindu. Mereka dikenal dengan orang orang yang menganut budaya yang membeda-bedakan. Hal ini terjadi merupakan sebuah keberhasilan bagi para penjajah terdahulu karena sistem ini secara langsung telah diadaptasi oleh masyarakat hindu di bali.

Perkawinan kasta di Bali ini sampai saat ini masih menunjukkan rintangan dan pertentangan didalam sebuah keluarga hal ini terjadi karena penyimpangan ini telah mengsalahartikan dari konsep catur warna yang terdapat dalam kitab suci Veda. Kesalahpahaman yang terjadi selama berabad-abad dalam penerapannya mengubah catur warna menjadi catur wangsa (kasta) di Bali. Hal ini dapat ditunjukkan dalam kehidupan seharihari seperti sikap dalam kehidupan bersosialisasi, kekuasaan yang diraih, dan kepanditaan atau orang yang dianggap suci.

Dalam sikap sosial, masyarakat yang menganut unsur ketimuran secara umumnya dan sebagian umat Hindu di Bali secara khususnya sangat patuh dan tunduk akan mereka yang memiliki kapasitas sebagai golongan kalangan atas atau elite yang menduduki sebuah jabatan dalam pemerintahan dan juga orang yang memiliki kasta tertinggi. Dalam konteks kekuasaan Kesalahpahaman dalam penerapan catur warna ini disebabkan oleh berkuasanya para kolonial Belanda seperti perkara tentang pelanggaran sistem wangsa yang akan dimenangkan oleh Belanda yang sangat jelas telah melanggar hak asasi manusia.

Kesalahpahaman dalam penerapan catur warna ini juga adalah tentang sistem kepanditaan. Sistem kepanditaan hingga kini ada beberapa yang masih menganut ajaran bahwa hanya perihal keagamaan dimonopoli oleh satu katurunan saja yaitu yang berasal dari kasta tertinggi dan hal ini berdampak sangat luas. Bagi mereka yang meyakini bahwa orang-orang yang berhak menjadi pendeta atau pemuka agama hanya untuk orang-orang yang menggunakan gelar pedanda. Sering kali sikap hormat kepada pendeta ini disalahgunakan oleh beberapa oknum dan hal ini telah dianggap sebagai media pembodohan atau penyimpangan dalam kurun waktu yang cukup lama. Kesalahpahaman ini masih terus berlanjut hingga saat ini. Di era yang 


\section{G.A. Amanda Kristina Damayanti}

serba canggih ini atau biasa dikenal dengan istilah milenial segala sesuatunya mudah didapatkan hanya dengan menggunakan media online, termasuk dalam mencari pasangan. Tak hayal lagi semua didapatkan melalui sebuah perangkat yang dapat menghubungkan semua orang dari segala penjuru dunia. Tak kenal batas waktu dan wilayah semua orang dapat terhubung hanya dalam satu aplikasi secara online. Namun tak banyak juga yang masih mengandalkan lewat perkenalan dan pertemuan di dunia nyata.

Tak ada masalah yang terjadi jika kedua belah pihak yang telah saling mengenal baik online maupun offline melanjutkan kejenjang yang lebih serius, namun balik lagi dengan melihat latar belakang masing masing pihak, dimana dalam budaya indonesia pernikahan terjadi bukan hanya antara kecocokan kedua belah pihak, melainkan mencocokan budaya dan adat istiadat yang dianut serta agama dan kepercayaan yang dianut antara kedua keluarga besar. Hal inilah yang biasa menjadi pro dan kontra ketika anak milenial akan melangsungkan pernikahan.

Pernikahan di era kekinian atau yang dikenal milenial ini memiliki beban ekspektasi yang tinggi, sehingga hal ini akan menimbulkan pro dan kontra. Pro karena lebih kepemikiran rasional berdasarkan akal dan logika sedangkan kontra karena lebih mementingkan gengsi, martabat dan harga diri belaka. Inilah yang terjadi pada generasi milenial Hindu di Bali yang akan segera melangsungkan kejenjang hubungan yang berikutnya. Dimana masih banyak masyarakat yang masih menganut sistem kasta atau wangsa menunjukan perlakuan diskriminasi. Hal ini dapat dilihat antara seseorang yang memiliki kasta tinggi akan bertentangan dengan orang yang berkasta rendah. Namun hal ini akan sangat kontras terjadi apabila pihak perempuan yang memiliki kasta tinggi dibanding kasta pihak laki-laki. Di Bali penyimpangan pernikahan beda kasta ini terjadi apabila Anak perempuan yang akan menikah dengan anak laki-laki yang memiliki kasta dibawah dikenal dengan istilah nyerod. Apabila anak perempuan ini tetap nekad untuk menikah dengan anak laki-laki ini dan memutuskan untuk mengikuti pihak laki-laki maka anak perempuan ini akan kehilangan hak untuk beribadah di merajan/sanggah milik keluarga, dan jika anak perempuan ini akan memiliki seorang anak, anak tersebut tidak akan berada disatu keturunan leluhur keluarga pihak perempuan.

Beda halnya dengan laki-laki berkasta rendah yang menikahi perempuan berkasta tinggi dimana laki-laki ini akan dipinang oleh pihak perempuan atas dasar persetujuan kedua 


\section{G.A. Amanda Kristina Damayanti}

keluarga. Hal ini dikenal dengan istilah nyentana. Nyentana merupakan kebalikan dari nyerod. Dimana anak laki-laki ini akan ikut bersama pihak perempuan dan apabila mereka memiliki keturunan, keturunan mereka akan masuk dalam silsilah keluarga perempuan. Namun hal ini jarang terjadi. Biasanya nyentana terjadi apabila dalam sebuah keluarga semua keturunannya berjenis kelamin perempuan. Keluarga yang tidak memiliki anak laki-laki atau semua keturunannya merupakan anak perempuan, akan sangat menginginkan apabila salah satu anaknya untuk tetap tinggal dirumah. Hal ini dikarena harus ada yang melanjutkan silsilah keluarga atau keturunan mereka. Alasan itulah yang menjadikan sebuah keluarga memiliki pemikiran tersebut. Jika seorang laki-laki telah bersedia untuk nyentana atau ikut dengan istri, maka mereka akan diistimewakan di rumah pihak perempuan karena sebagai bentuk terima kasih karena telah bersedia melanjutkan keturunan mereka. Sesungguhnya tak ada larangan jika masih menggunakan sistem ini hanya saja jika masih terjadi perlakuan diskriminasi maka sistem ini harus segera ditinggalkan.

Dengan pemahaman dan pengetahuan yang kurang dimiliki oleh masyarakat terhadap catur Warna menyebabkan kesalahpahaman didalam penerapannya sehari-hari, banyak yang menyamakan antara sistem Kasta dengan catur Warna. jika didalam sistem Kasta, golongan tertinggi yaitu golongan Brahmana, namun didalam catur Warna semua golongan memiliki tingkat kedudukan yang sejajar atau sama, baik itu golongan Sudra, golongan Waisya, golongan Ksatriya, dan golongan Brahmana, semua memiliki tingkat atau kedudukan yang mulia. Semua dapat mengabdi dan saling bergotongroyong sebesar mungkin dan dapat melaksanakan semua tugasnya dengan penuh rasa cinta kasih serta keikhlasan dari hati yang terdalam.

Pada era yang serba canggih ini tak jarang hal ini tak terlalu menjadi permasalahan dalam kehidupan hanya saja yang biasa terjadi adalah ketika akan memulai kehidupan kedua keluarga yang akan segara disatukan melalui pernikahan dalam keturunannya akan memperdebatkan siapa yang akan masuk dan keluar dari silsilah keluarga mereka, tentang siapa yang akan mewarisi harta keluarga, dan siapa yang akan melestarikan tempat suci yang ada dirumah masing-masing pihak, karena kepercayaan akan leluhur yang masih kental menjadikan ini sebagai perdebatan yang tak ada ujungnya. sehingga tak jarang pula banyak masyarakat yang memilih untuk pindah agama atau mencari pasangan dari luar daerah yang memiliki latar belakang budaya yang berbeda dan dengan mudah didapatkan melalui sosial 


\section{G.A. Amanda Kristina Damayanti}

media. Tak jarang pula yang mengabaikan dan menentang tradisi ini sehingga mereka lebih memilih untuk pergi dan tinggal merantau jauh dari daerah asal.

Hal yang terjadi saat ini adalah perbedaan penggunaan sistem kasta di Indonesia saat ini mulai mengalami penurunan dalam pelestariannya yang luntur karena jaman modernisasi yang semakin hari semakin modern. Banyak masyarakat yang telah menyadari bahwa sekarang ini jaman telah berubah dan berbeda dengan jaman terdahulu yang pada saat itu masih berdiri banyak kerajaan. Saat ini Indonesia sudah berbentuk negara demokrasi bukan kerajaan seperti jaman dulu . Adanya sistem kasta di Indonesia bukan merupakan sebuah hal yang buruk atau yang fatal bila terjadi, tetapi kasta juga jika dilaksanakan dengan baik dapat berfungsi sebagai jati diri daerah atau ciri-ciri daerah asal. Namun dengan tidak melakukan penyimpangan dengan menyalah artikan bahwa yang "berkasta adalah yang memiliki kuasa". Indonesia merupakan negara demokrasi. Indonesia menjunjung tingggi Bhineka Tunggal Ika, jadi tidak ada perbedaan yang signifikan antar sesama manusia, perbedaanlah yang akan menyatukan seluruh elemen masyarakat kita menjadi bangsa Indonesia satu.

Adanya kasta dan catur warna ini hendaknya disikapi dengan sikap positif tanpa adanya paksaan atau suatu yang mengharuskan, jika masih menggunakan sistem kasta maka hendaknya seseorang tidak untuk memaksa orang lainnya untuk menganut sistem ini, dengan menemukan seseorang yang sejalan dengan pandangan dan pedoman hidup, agar semua dapat terjalankan dengan baik dan dapat melestarikan hal yang sudah ada sejak jaman dahulu. Namun sebagai umat yang memegang teguh agama dan hidup berdasarkan pedoman kitab suci, hendaknya seseorang dapat mematuhi seluruh aturan yang telah ditetapkan dan yang telah ada sejak jaman terciptanya alam semesta. Kitab suci telah mengatur golongan-golongan yang ada agar terjadi kesetaraan dengan tidak membeda bedakan seluruh mahluk hidup sehingga adanya catur warna ini dapat menjadi suatu arahan yang mengatur kehidupan sosial dalam dengan seluruh elemen masyarakat dan hubungan yang terjadi diantara golongan pada catur warna hanya dibatasi oleh "dharma" dan kewajiban yang berbeda-beda tetapi semua akan tetap memiliki satu tujuan yakni kesempurnaan hidup.

\section{Simpulan}

Konsep catur Varna dewasa ini dikaburkan dengan Catur Kasta sehingga terjadi banyak polemic terutama dalam hal perkawinan para generasi antar varna yang berbeda. Hal tersebut menyebabkan pro dan kontra, walau pada hakekanya keberadaan catur varna yang dapat diakui 


\section{G.A. Amanda Kristina Damayanti}

sebagaimana tertuang dalam beberapa bait kitab suci hindu. Catur Varna merupakan empat penggolongan masyarakat berdasarkan profesinya, yang terdiri dari brahmana, ksatria, weisya dan dan sudra. Brahmana merupakan golongan orang-orang cendekiawan yang mampu menguasai ajaran, ilmu pengetahuan, adat, adab hingga ajaran keagamaan. Ksatriya dalam catur varna merupakan golongan yang dianggap sebagai bangsawan pada masa lampau yang juga merupakan golongan para kesatria ataupun para prajurit raja. Ksatriya berperan sebagai pelindung yang menggunakan seluruh kekuatan tangannya untuk melindungi negara beserta isinya. Waisya memiliki keahlian dan tugas dibidang perdagangan atau perekonomian yang bersifat materil. Pada jaman dahulu kasta waisya ini erat kaitannya dengan orang yang berprofesi sebagai pedagang, namun saat ini sudah banyak yang menjadi pedagang walau bukan berasal dari keturunan pedagang, sehingga layak untuk dimasukan dalam kelompok waisya. Sudra merupakan sebuah golongan yang memiliki profesi dan juga keahlian yang mengandalkan kekuatan jasmani atau tenaga yang dimiliki. Kelompok sudra dapat masuk dalam golongan lainnya apabila telah menekuni profesi dalam golongan lainya tersebut. Konsep ini menguraikan bahwa bukanlah keturunan yang menentukan status seseorang meskipun seseorang tersebut lahir, tumbuh dan besar dalam keluarga Sudra atau Waisya belum tentu seseorang tersebut menyandang gelar tersebut, akan tetapi apabila seseorang tersebut telah menekuni bidang kerohanian dan menjadi seorang pendeta, maka ia secara langsung berhak menyandang status Brahmana (rohaniawan).

Perkawinan kasta di beberapa wilayah saat ini masih menunjukkan rintangan dan pertentangan didalam sebuah keluarga. Pertentangan terjadi karena telah keliru dalam mengartikan konsep catur warna yang terdapat dalam kitab suci Veda. Terdapat banyak masyarakat yang masih menganut sistem kasta atau wangsa sehingga menunjukan perlakuan diskriminasi. Pernikahan berbeda varna dianggap dapat berpengaruh terhadap status sosial seseorang, karena menganggap bahwa varna adalah kasta sehingga berdampak pada adanya istilah nyerod.

\section{Daftar Pustaka}

Aditi, I. G. A. (2019). Problematic and alternative solutions of different wangsa marriage at Balinese community in Lombok. International Journal of Social Sciences and Humanities, 3(2), 84-94. https://doi.org/10.29332/ijssh.v3n2.296

Bandana, I. G. W. S. (2015). Sistem Nama Orang Bali: Kajian Struktur dan Makna. Aksara, 27(1),1-11. Diambil darihttp://dx.doi.org/10.29255/aksara.v27i1.166.1-11 


\section{Problematika Pernikahan Generasi Milenial Terhadap Kasta Di Bali}

\section{G.A. Amanda Kristina Damayanti}

Cahyono, Indah Dugi. Kedudukan Sentana Nyeburin dalam Perkawinan Nyentana Menurut Hukum Adat Waris Bali. Tesis. Semarang: Program Pascasarjana Universitas Diponogoro 2002.

Dewi, I. A. M. L. (2013). Implikasi perkawinan beda kasta dalam perspektif hukum, sosialbudaya dan religius di Banjar Brahmana Bukit, Kecamatan Bangli, Kabupaten Bangli. Jurnal Pendidikan KewarganegaraanUndiksha, 1(6).

Kerepun, Made Kembar. 2007. Mengurai Benang Kusut Kasta Membedah Kiat Pengajegan Kasta di Bali. Denpasar: Empat Warna Komunikasi.

Sudarsini, Ni Nengah. "Kasta dan warna: sebuah kritik dalam masyarakat egaliter." Pangkaja: Jurnal Agama Hindu 21.1 (2018).

Wiana, Ketut dan Raka Santri. 2005. Kasta dalam Hindu: Kesalahpahaman Berabad-abad. Cetakan Pertama. Denpasar: Yayasan Dharma Naradha.

Wiana, Ketut. Memahami Perbedaan Catur Warna, Kasta dan Wangsa. Surabaya: Paramita, 2006. 